\title{
Peningkatan Kompetensi Bahasa Inggris bagi Dosen FKIP Universitas Mathla'ul Anwar Banten
}

\author{
Ade Sudirman ${ }^{1}$, Nur Azmi Rohimajaya ${ }^{2}$ \\ 1,2 Universitas Mathla'ul Anwar Banten
}

\begin{tabular}{l}
\hline ARTICLE INFO \\
\hline Article History: \\
Received 30.08.2018 \\
Received in revised \\
form 15.11.2018 \\
Accepted 19.12.2018 \\
Available online \\
26.12.2018
\end{tabular}

\begin{abstract}
This community service activity is motivated by the thought that the need for lecturers to have good competence in using English in the teaching and learning process in the classroom. With the hope that through its application, students become more enthusiastic in learning. The purpose of this community service activity is to provide scientific assistance to the lecturers of FKIP Unma Banten in using English in the teaching and learning process. While the benefits of this activity are to have a positive effect on the lecturers of FKIP Unma Banten in communicating using English in class and the increasing enthusiasm and achievement of FKIP Unma Banten students in learning. This service activity was carried out in the form of short training for two meetings with members of 10 lecturers held in the hall of FKIP Unma Banten. The first meeting discussed the importance of English, introducing word, clause, and sentences, mastering tenses by using smart fingers technique. The second meeting was a deepening of the material followed by the practice of TOEFL questions and the practice of speaking English in everyday life with simple sentences by participants of FKIP Unma Banten lecturers. The method used in this community service activity is the lecture method, question and answer, discussion and demonstration methods. Based on observations during this community service activity, several positive results were obtained. The results of this community service are the increased insight of FKIP Unma Banten lecturers on English language material and its application in the teaching and learning process in the classroom.
\end{abstract}

Keywords: English Competence, Lecturer, Unma Banten.

DOI: $10.30653 / 002.201832 .104$

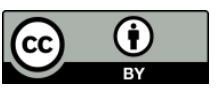

This is an open access article distributed under the terms of the Creative Commons Attribution 4.0 International License, which permits unrestricted use, distribution, and reproduction in any medium, provided the original work is properly cited. @ 2018 Ade Sudirman, Nur Azmi Rohimajaya.

\section{PENDAHULUAN}

Pada era global saat ini, bahasa Inggris mempunyai peranan yang sangat penting dalam kehidupan sehari-hari. Bahasa Inggris merupakan bahasa internasional yang digunakan untuk berkomunikasi. Sebagai bahasa internasional, bahasa Inggris digunakan

${ }^{1}$ Corresponding author: Program Studi Pendidikan Bahasa Inggris FKIP Unma Banten. Jl. Raya Labuan KM. 23 Cikaliung, Saketi, Pandeglang, Banten 42273, Indonesia; Email: adesudirman03@gmail.com. 
sebagai sarana komunikasi di sektor ekonomi, sosial, politik, budaya dan pendidikan antara negara yang satu dengan negara yang lainnya. Bahasa Inggris menjadi bahasa yang menjembatani transfer informasi dan komunikasi dengan masyarakat setempat di negara yang dikunjungi.

Bahasa Inggris sebagai bahasa asing di Indonesia sudah diperkenalkan secara luas mulai usia dini baik di sekolah-sekolah formal maupun non-formal. Keahlian berbahasa asing ini diperlukan untuk menguasai ilmu pengetahuan, memiliki pergaulan luas dan karir yang baik. Sehingga hal ini membuat semua orang dari berbagai kalangan termotivasi untuk menguasai bahasa Inggris. Kecenderungan masyarakat akan penguasaan bahasa asing tersebut, menjadikan beberapa lembaga pendidikan saling berlomba untuk menyelenggarakan program yang menjadikan bahasa Inggris sebagai salah satu keahlian yang dikembangkannya.

Bahasa Inggris merupakan salah satu keahlian (skill) yang harus dimiliki oleh seluruh dosen untuk menunjang proses pendidikan yang lebih baik. Dengan memiliki kompetensi bahasa Inggris yang baik, maka akan tercipta dosen-dosen yang berkualitas. Ini menjadi hal penting mengingat dosen merupakan sumber daya manusia (SDM) yang akan mendorong pencapaian yang baik untuk universitas yang menaunginya. Oleh karena itu, perlu diadakan program khusus yang diikuti para dosen tentang pengajaran di kelas dengan menggunakan bahasa Inggris. Kegiatan ini bertujuan untuk memberikan pengetahuan kepada para dosen dalam mengajar dengan menggunakan bahasa Inggris. Dan hal ini juga yang mendorong tim pengabdian kepada masyarakat untuk mengadakan pelatihan bahasa Inggris bagi dosen-dosen di Fakultas Keguruan dan Ilmu Pendidikan (FKIP), Universitas Mathla'ul Anwar (Unma) Banten melalui "Short Course of English; Introducing Basic English Materials."

\section{METODE PELAKSANAAN}

Kegiatan pengabdian ini dilaksanakan dalam bentuk sebuah pelatihan singkat selama dua kali pertemuan dengan anggota sebanyak 10 orang dosen FKIP, Unma Banten yang dilaksanakan di aula FKIP, Unma Banten. Metode yang digunakan dalam melaksanakan kegiatan pengabdian kepada masyarakat ini adalah metode ceramah, tanya jawab, diskusi dan demonstrasi.

Pertemuan pertama berlangsung pada hari Rabu, 11 April 2018, selama 120 menit. Pada pertemua ini dibahas tentang pentingnya bahasa Inggris (the importance of English), pengenalan kata, klausa dan kalimat dasar bahasa Inggris (introducing of word, clause, and sentences), dan Penguasaan tensis bahasa Inggris dengan teknik Smart Fingers (mastering tenses by using smart fingers technique).

Pertemuan kedua merupakan pendalaman terhadap materi dengan cara mengerjakan latihan soal-soal dan praktik berbicara bahasa Inggris di kehidupan seharihari dengan kalimat yang sederhana oleh peserta dosen-dosen FKIP Unma Banten. Pada sesi latihan soal bahasa Inggris, para peserta diberikan beberapa stategi dalam menjawab soal-soal TOEFL. Sementara untuk praktek berbicara (speaking), para peserta diminta untuk berlatih mendeskripsikan benda atau orang, dan ungkapan-ungkapan yang biasa digunakan dalam kehidupan sehari-hari dengan menggunakan bahasa Inggris.

Terdapat dua langkah pelaksanaan kegiatan, yaitu: 1) Tim pengabdian membahas materi; 2) Tim pengabdian memberikan latihan terkait materi. Adapun kegiatan yang 
dilakukan dalam mencapai tujuan pengabdian kepada masyarakat ini adalah sebagai berikut:

\section{Persiapan}

1) Mengurus surat izin dan surat tugas untuk melaksanakan kegiatan pengabdian kepada masyarakat.

2) Menghubungi pihak FKIP Unma Banten untuk menetapkan jumlah peserta dan jadwal pelaksanaan pengabdian kepada masyarakat.

Pelaksanaan

Kegiatan pengabdian kepada masyarakat ini dilaksanakan pada hari Rabu, tanggal 11 dan 18 April 2018 di aula FKIP Unma Banten. Masing-masing pertemuan berlangsung selama 120 menit. Sebagai peserta dari kegiatan pengabdian kepada masyarakat ini adalah para dosen FKIP Unma Banten, yang terdiri dari dosen jurusan Matematika, bahasa Indonesia, dan bahasa Inggris.

\section{HASIL DAN PEMBAHASAN}

Kegiatan pelatihan bahasa Inggris bertajuk "Short Course of English: Introducing Basic English Materials" ini diadakan pada hari Rabu, tanggal 11 dan 18 April 2018 pada pukul 10.00 sampai dengan 12.00 WIB. Kegiatan tersebut dihadiri oleh 10 peserta yang terdiri dari dosen-dosen dari jurusan Matematika, bahasa Indonesia dan bahasa Inggris di lingkungan FKIP Unma Banten.

Undangan pelatihan disampaikan kepada para peserta seminggu sebelum kegiatan dimulai melalui aplikasi WhatsApp group. Kegiatan diadakan di Aula FKIP Unma Banten. Berdasarkan pengamatan selama kegiatan pengabdian kepada masyarakat berlangsung, diperoleh beberapa hasil yang positif, diantaranya adalah:

1) Para peserta menunjukkan perhatian yang sangat tinggi terhadap materi pelatihan yang disampaikan oleh tim pengabdian.

2) Para peserta menunjukan reaksi yang positif terhadap materi pelatihan yang disampaikan oleh tim pengabdian.

3) Para peserta aktif bertanya dan mengungkapkan masalah-masalah yang dialaminya selama ini dan mereka bersemangat untuk menggunakan bahasa Inggris dalam proses belajar mengajar di kelas.

4) Para peserta terlihat kompak dan menjalin kerja sama yang cukup baik dalam latihan soal-soal dan praktek berbicara bahasa Inggris.

Ditinjau dari segi materi pelatihan yang disampaikan, banyak pengalaman, pengetahuan dan keterampilan baru yang diperoleh oleh para dosen FKIP Unma Banten yang berperan sebagai pesertanya. Sebaliknya, bagi tim pengabdian juga memperoleh beberapa input yang bermanfaat tentang berbagai masalah dan kendala yang dialami oleh para dosen FKIP Unma Banten dalam menggunakan bahasa Inggris pada proses belajar mengajar di kelas. Dengan pengalaman tersebut, tim pengabdian akan menggunakannya sebagai bahan pertimbangan untuk melaksanakan pengabdian kepada masyarakat di masa yang akan datang.

Secara umum, kegiatan pelatihan "Short Course of English: Introducing Basic English Materials" yang dilaksanakan oleh tim pengabdian masyarakat ini tidaklah menemukan 
kendala yang cukup berarti. Dengan demikian, bahwa pelaksanaan pengabdian kepada masyarakat ini berjalan dengan lancar dan sesuai dengan target.

\section{SIMPULAN}

Berdasarkan uraian yang telah dikemukakan sebelumnya, diperoleh kesimpulan bahwa kegiatan pengabdian kepada masyarakat ini dapat: 1) Meningkatkan pengetahuan dan keterampilan dosen-dosen FKIP Unma Banten dalam menggunakan bahasa Inggris pada proses belajar mengajar di kelas; 2) Meningkatkan semangat dosen-dosen FKIP Unma Banten dalam memberikan pelayanan yang terbaik kepada para mahasiswa FKIP Unma Banten; 3) Memberikan kesempatan tim pengabdian kepada masyarakat untuk mengamalkan ilmunya dalam kaitan melaksanakan salah satu Tridharma Perguruan Tinggi.

Berdasarkan kepada hasil yang diperoleh maka dapat disarankan beberapa hal sebagai berikut: 1) Berdasarkan permintaan dari peserta, hendaknya kegiatan-kegiatan seperti ini dapat ditingkatkan waktu/ intensitas pelaksanaanya; 2) Biaya untuk pelaksanaan kegiatan ini hendaknya lebih ditingkatkan, sehingga dapat melaksanakan kegiatan lebih variatif dan waktu lebih lama.

\section{REFERENSI}

Azar, B. S. (2003). Fundamental of english grammar, third edition with answer key. New York: Pearson Education.

Decapua, A. (2008). Grammar for teacher: A guide to american english for native and non-native speakers. New York: Springer.

Philips, D. (2001). Longman complete course for the TOEFL test: Preparation for the computer and paper tests. New York: Pearson Education.

Sudirman, A. (2012). Smart fingers: Menguasai 16 tenses bahasa inggris dengan jari dalam 30 menit!. Bandung: Khazanah Intelektual. 